\title{
Ekim zamanının Amik Ovası koşullarında yetiştirilen bazı mısır (Zea mays L.) çeşitlerinde ot verimi ve kalitesine etkisi
}

Effects of sowing dates on forage yield and quality of cultivated some maize (Zea mays L.) cultivars under Amik Lowland conditions

\author{
Merve ATASEVER ${ }^{1}$ (D) Şaban YILMAZ ${ }^{1 \mathscr{Q}}$ (D) , ibrahim ERTEKIN $^{1}$ \\ ${ }^{1}$ Hatay Mustafa Kemal University, Faculty of Agriculture, Department of Field Crops, Antakya-Hatay, Turkey.
}

MAKALE BILGISI / ARTICLE INFO

\section{Makale tarihçesi / Article history:}

DOI: $10.37908 /$ mkutbd.694216

Geliş tarihi /Received:25.02.2020

Kabul tarihi/Accepted:10.06.2020

\section{Keywords:}

B Sowing dates, Maize cultivars, Forage yield, Forage quality.

\footnotetext{
Corresponding author: Şaban YILMAZ

$\bowtie$ : sayilmaz@mku.edu.tr
}

\author{
ÖZET / ABSTRACT
}

Atıf / Citation: Atasever M, Yılmaz Ş, Ertekin I (2020) Ekim zamanının amik ovası koşullarında yetiştirilen bazı mısır (Zea mays L.) çeşitlerinde ot verimi ve kalitesine etkisi. MKU. Tar. Bil. Derg. 25(3) : 326-340. DOI: $10.37908 /$ mkutbd.694216 


\section{Gíiş̧}

Mısır bitkisi $\mathrm{C}_{4}$ bitkileri içerisinde bulunmasından dolayı güneş enerjisinden en etkin yararlanan bitkilerden biridir. Ülkemizde tarımı yapılan yem bitkileri içerisinde yoncadan sonra en fazla ekim alanına sahip türdür. Mısır onlarca kullanım alanına sahip bir bitki türü olmasından dolayı sanayi alanında popülerliğini her geçen gün arttırmıştır. Bu bitki hayvan beslemede hem hasıl hem de silaj olarak kaba yem amacıyla kullanılmaktadır. Ayrıca daneleri yem sanayisinde kesif yem ham maddesi olarak yoğun bir şekilde kullanılmaktadır. Türkiye'de mısır ekim alanları 2010 yılından 2018 yılına kadar sürekli bir artış içerisindedir (Anonim 2018). Bu bitkinin bahsedilen bu olumlu özelliklerinden dolayı gün geçtikçe çiftçiler tarafından daha da fazla ekilmekte, buda bitkinin yetiştirme periyodu boyunca erken ekimini önemli kılmaktadır. Böylece mısır yetiştiriciliğini hem tane üretimi hem de kaba yem üretimi amacıyla gerçekleştiren çiftçilerimiz erken ekimin getirmiş olduğu avantajlardan faydalanarak bir yetiştirme sezonunda birden fazla kez bitkisel üretim olanağı elde edebilecektir.

Mısırın hayvan besleme açısından artan önemliliğinden dolayı her geçen gün hasıl ve silajık mısır çeşitleri tescil edilerek piyasaya sunulmaktadır. Dahası, bazı üreticiler tahıl üretimi amacıyla tescil ettirilen çeşitleri bile hasıl ve/veya silaj üretimi için yetiştirebilmektedir. Bu çeşitlerin yetiştirilen bölgeye uygunluğunun belirlenmesi büyük önem arz etmektedir. Mısır çeşitleri arasında erkenci çeşitler olduğu gibi geç olgunluğa ulaşan çeşitler de bulunmaktadır. Özellikle iklim koşullarının bir yılda birden fazla ürün almaya elverişli olduğu bölgelerde çitçilerin bu konuya çok dikkat etmesi gerekmektedir (Koca ve Erekul 2011). Çukurova ve Amik ovası koşullarında yapılan bazı araştırmalarda mısırda en yüksek hasıl veriminin erken ekimlerden elde edildiği ve ekim zamanı geciktikçe verimin azaldığı, ek olarak verimin çeşitlerden de etkilendiği saptanmıştır (Konak ve Demir 1987; Sağlamtimur 1989; Laurer ve ark. 1999; Yılmaz ve ark. 1999; Yılmaz ve ark. 2007).

Erken dönemde silajlık mısır ekimiyle birlikte hem arazi kullanım etkinliğini arttırmak hem de kış yağışlarından faydalanarak sulama giderlerinin azaltılması planlanmaktadır. Ayrıca kış dönemlerinde hayvan besleme açısından ortaya çıkan yem problemlerini giderme potansiyelini belirlemek ve bölgede yaygın ekimi yapılan havuç tarımı için ön bitkinin araziyi erken terk etmesini sağlamak oldukça önemlidir. Bu çalışma, Amik ovası koşullarında erken birinci ürün mısırda yaygın kültürü yapılan bazı silajlık ve dane mısır çeşidini ve ekim zamanı belirlemek amacıyla yürütülmüştür.

\section{MATERYAL ve YÖNTEM}

\section{Materyal}

Bu çalışma, ekim zamanının Amik ovası koşullarında yaygın yetiştirilen bazı mısır (Zea mays L.) çeşitlerinin ot verimi ve kalitesi üzerine etkisini belirlemek için Reyhanlı çitçi tarlasında 2017 yılında ana ürün ekimiyle bir yıl süreyle yürütülmüştür. Araştırmada kullanılan mısır çeşitleri bölgede en yaygın kültürü yapılan çeşitlerdendir ve bunların ticari adları P31P41, 70 MAY 82, DKC 6590 ve CARELLA F1 şeklinedir.

Denemenin kurulduğu topraklar zirai potansiyeli çok yüksek kalın bir alüvyal toprak tabakası ile kaplı olup, aynı zamanda ilin en büyük toprak düzlüğünü oluşturur. Deneme alanının toprak özellikleri 0-30 cm derinliğinden alınan numune örneğinin Antakya Ticaret Borsası Toprak, Yaprak ve Su Analiz Laboratuvarından alınan analiz sonuçlarına göre, deneme alanının toprağı KilliTınlı bünyede, tuzluluk yapısı önemsiz seviyede, Araştırmanın yürütüldüğü bölgeye ait Şubat 2017Ağustos 2017 dönemi iklim verileri Çizelge 1'de verilmiştir. Çizelge 1'de görüldüğü gibi 2017 yılına ait ortalama maksimum sıcaklık en yüksek Temmuz, ortalama minimum sıcaklığın ise en yüksek Ağustos, ortalama yağışın en fazla Nisan ayında olduğu, en yüksek nispi nem değerinin ise Mart ayında olduğu saptanmıştır. Araştırmanın yürütüldüğü bölgeye ait uzun yıllar ortalamasına bakıldığında ise maksimum sıcaklık, minimum sıcaklık ve ortalama sıcaklığın arttığı toplam yağışın ise büyük oranda düştüğü görülmektedir. Bu durumda, deneme yılında uzun yıllar ortalamasına göre sıcak ve kurak bir yıl geçtiği söylenebilir.

\section{Yöntem}

Bu çalışma amik ovası koşullarında yaygın yetiştirilen bazı mısır çeşitlerinin farklı ekim zamanlarında ot verimi ve kalitesini belirleyebilmek için 2017 yılında tesadüf bloklarında bölünmüş parseller deneme desenine göre üç tekrarlamalı olarak yürütülmüştür. Ekim zamanları 25 Şubat, 14 Mart ve 30 Mart olmak üzere ana parsellere ve mısır çeşitleri P31P41, 70 MAY 82, DKC 6590 ve CARELLA F1 olmak üzere alt parsellere dağıtılmıştır. Ekim sıraya ekim şeklinde planlanmış ve sıra arası mesafe $70 \mathrm{~cm}$, sıra üzeri mesafe ise $15 \mathrm{~cm}$ olarak uygulanmıştır. 5 metre uzunluğundaki her parsel 7 sıradan oluşmuştur. Bloklar arsında 3'er metre boşluk bırakılmış ve ekim işlemi 3-5 cm'lik derinliğe elle yapılmıştır. Araştırma bir önceki yıl soğan yetiştirilmiş ve yaz periyodunda nadasa bırakılmış arazi üzerinde kurulmuştur. Çalışma arazisine ekimden önce $1 \mathrm{~kg} \mathrm{da}^{-1}$ sıvı halde humik asit uygulanmıştır. Toprağa ekimden önce saf $6 \mathrm{~kg} \mathrm{da}^{-1}$ NPK düşecek şekilde 15-15-15 taban gübresi serpilmiştir. Ekimden önce 
sıralar boş tohum mibzeri ile açılmış ve daha sonra parselasyon işlemleri yapılmıştır. 25 Şubat ve 14 Mart ekimleri yağmurlama sulama ile 30 Mart ekimleri ise tankerle salma sulama şeklinde yapılmış ve bitkilerin homojen çıkışına katkı sağlanmıştır. Deneme arazisinde
30 Mart ekim tarihinde 25 Şubat ekim tarihine ilk çapa traktör ile yapılmıştır. Illk çapadan on gün sonra ikinci çapa, ikinci çapadan 10 gün sonra yine üçüncü çapa traktör vasıtasıyla yapılmıştır.

Çizelge 1 Araştırma yılı ve uzun yıllar ortalamasına ilişkin bazı önemli iklim değerleri

Table 1. Some significant meteorological data of 2017 and many years

\begin{tabular}{llllllll}
\hline AYLAR & $\begin{array}{l}\text { YIL/UZUN } \\
\text { YILLAR }\end{array}$ & Mak. Sic. $\left({ }^{\circ} \mathrm{C}\right)$ & Min. Sic. $\left({ }^{\circ} \mathrm{C}\right)$ & Ort. Sic. $\left({ }^{\circ} \mathrm{C}\right)$ & $\begin{array}{l}\text { Ort. } \\
(\%)\end{array}$ & $\begin{array}{l}\text { Nis. } \\
(\% .\end{array}$ & $\begin{array}{l}\text { Top. } \\
(\mathrm{mm})\end{array}$ \\
\hline Şubat & 2017 & 23.7 & -5.9 & 8.3 & 56.7 & 1.4 \\
U.Y.O. & $1940-2016$ & 26.6 & -6.8 & 9.9 & - & 170.4 \\
Mart & 2017 & 24.2 & 1.8 & 13.5 & 70.6 & 12.4 \\
U.Y.O. & $1940-2016$ & 30.5 & -4.2 & 13.1 & - & 143.1 \\
Nisan & 2017 & 33.2 & 4.8 & 17.3 & 60.6 & 27.4 \\
U.Y.O. & $1940-2016$ & 37.5 & 1.5 & 17.2 & - & 103.2 \\
Mayıs & 2017 & 36.2 & 11.6 & 21.7 & 56.8 & 26.8 \\
U.Y.O. & $1940-2016$ & 42.5 & 7.7 & 21.2 & - & 78.6 \\
Haziran & 2017 & 38.2 & 14.9 & 26.4 & 54.4 & 0.0 \\
U.Y.O. & $1940-2016$ & 43.2 & 11.6 & 24.8 & - & 24.7 \\
Temmuz & 2017 & 45.2 & 18.8 & 30.1 & 49.6 & 0.0 \\
U.Y.O. & $1940-2016$ & 43.4 & 15.9 & 27.1 & - & 6.9 \\
Ağustos & 2017 & 43.7 & 20.5 & 29.3 & 61.3 & 0.0 \\
U.Y.O. & $1940-2016$ & 43.9 & 15.4 & 27.7 & - & 6.8 \\
\hline UY.O; & & & & & \\
\hline
\end{tabular}

U.Y.O; Uzun Yıllar Ortalaması, Mak. Sıc.; Maksimum Sıcaklık, Min. Sıc.; Minimum Sıcaklık, Ort. Sıc.; Ortalama Sıcaklık, Ort. Nis. N.; Ortalama Nispi Nem, Top. Yağ.; Toplam Yağış

Bitkiler diz boyuna gelince çapalı gübre makinası ile 4.6 $\mathrm{kg} \mathrm{da}^{-1} \mathrm{~N}$, üre gübresi kullanılarak verilmiştir. Çalışmanın yürütüldügü ekim alnında son ekimden yaklaşık 20 gün sonra öncelikle yabancı otlar ile mücadele kapsamında otlar elle ve makina ile temizlenmiştir. Otlar temizlendikten sonra yeni çıkacak otları ve gözden kaçan otları öldürmek amacıyla holder ile herbisit olarak içeriği $225 \mathrm{~g} \mathrm{l}^{-1}$ Isoxaflutole, $90 \mathrm{~g} \mathrm{I}^{-1}$ thiencarbazone-methyl, 150 $\mathrm{g}^{-1}$ cyprosulfamide olan yabancı ot ilacı atılmıştır. illk sulamadan önce araziye holder ile dekara $100 \mathrm{~g}$ humik asit ile birlikte sap kurdu ilacı atılmıştır. Son ekim tarihinden yaklaşık 35 gün sonra sulama kanallarına sifon adı verilen su boruları yerleştirilmiştir. Ekim zamanlarının bazı mısır çeşitlerinde ot verimi ve kalitesi üzerine etkilerini belirlemek için yürütülen bu çalışmada sulama, 1. ekim tarihinde 6,2 . ekim tarihinde 7 ve 3 ekim tarihinde 8 sulama yapılmıştır. Ekim zamanının gecikmesiyle birlikte sulama sayısı artmıştır. Bu araştırmada kullanılan mısır çeşitleri süt olum döneminin sonu ve hamur olum döneminin başlangıcında (\%50 süt çizgisi oluştuğunda) hasat işlemine tabi tutulmuştur.
Bitki boyu için her parselden rasgele seçilen 10 bitki üzerinde ölçüm yapılmıştır. Rastgele seçilen bu bitkiler üzerinde ayrıca yaprak sayısı, sap çapı, yaprak ağırlığı, sap ağırlığı ve koçan ağırlığı özellikleri de ölçülmüştür. Yeşil ot verimi için hamur olum döneminin başlangıcında parseller biçilmiş ve parsel verimleri alınmıştır. Parsel verimleri üzerinden elde edilen değerler $\mathrm{kg} / \mathrm{da}$ cinsine dönüştürülmüştür. Her parselden alınan üç tüm bitki örneği parçalanmış ve tartılmıştır. Tartılan bu örnekler etüvde $65^{\circ} \mathrm{C}^{\prime}$ de kurumaya bırakılmış ve bitkilerin kuru ağırlıkları sabitleşince tartım yapılmıştır. Taze ve kuru ağırlık arasındaki farktan yararlanarak kuru ot oranları belirlenmiş ve bu oran üzerinden kuru ot verimleri hesaplanmıştır. Kuru yan bu bitkiler kimyasal analizlere hazırlanmak için $1 \mathrm{~mm}$ elek çapına sahip endüstriyel tip değirmende öğütülmüştür (Ertekin ve ark., 2019; Ertekin ve Kızılşimşek, 2020). ADF ve NDF Ankom Fiber Analyzer kullanılarak Van Soest ve ark. (1994)"nın açıkladığı yönteme göre belirlenmiştir. Örneklerin azot (N) içeriği Kjeldahl metoduna göre belirlenmiş (AOAC, 1990) ve ham protein için 6.25 katsayısı ile çarpılmıştır. Sindirilebilir kuru madde (SKM), Kuru madde 
tüketilebilirliği (KMT), Nispi yem değeri (NYD) ve Laktasyon Net enerji (NEL) değerleri NDF ve ADF değerleri kullanılarak aşağıdaki formüllerle (Van Dyke ve Anderson. 2002) hesaplanmıştır.

SKM = 88.9- $(0.779 \times \% A D F) ;(1)$

$\mathrm{KMT}=120 / \% \mathrm{NDF} ;(2)$

NYD $=\% S K M \times \% K M T \times 0.775 ;(3)$

$\mathrm{NEL}=(1.044-(0.0119 \times \%$ ADF $)) \times 2.205(4)$

Araştırmadan elde edilen değerler MSTAT-C istatistik paket programı kullanılarak "Tesadüf Bloklarında Bölünmüş Parseller Deneme Desenine" göre varyans analizine tabi tutulmuştur. $F$ testi yapılarak farklılıkları tespit edilen özelliklerin ortalama değerleri Duncan $(P<0.05)$ çoklu karşılaştırma testine göre gruplandırılmıştır.

\section{BULGULAR ve TARTIŞMA}

Yürütülen bu çalışmada farklı ekim zamanlarının bazı mısır çeşitlerinin ot verimi ve kalitesi üzerine etkilerini belirlemek için incelenmiş olan bitki boyu (BB), yaprak sayısı (YS) tepe püskülü çıkarama süresi (TPÇS), sap çapı (SÇ), yaprak ağırlığı (YA), sap ağırlığı (SA), koçan ağırlığı $(\mathrm{KA})$, yeşil ot verimi (YOV) ve kuru ot verimi (KOV) özelliklerine ait $F$ değerleri ve önemlilik durumları Çizelge 2 'de verilmiştir.

Çizelge 2'de görüldüğü gibi uygulanan faktörler ve bu faktörlerin interaksiyonu bitki boyu (BB) üzerine bir etkide bulunmamıştır fakat diğer incelenen tüm özellikler açısından uygulanan faktörlerden en az biri etki etmiştir. Bu açıdan BB dışında incelenen tüm verim özellikleri 0.01 ve/veya \%0.05 önemlilik seviyesinde uygulanan faktörlerin en az birinden etkilenmiştir.

Çizelge 2. Incelenen bazı verim parametrelerine ilişkin $\mathrm{F}$ testi ve önemlilik seviyeleri

Table 2. F test results and significance levels of investigated some yield parameters

\begin{tabular}{llllllllll}
\hline \multirow{2}{*}{ Faktörler } & & \multicolumn{9}{c}{ F Değerleri } & & \\
& BB & YS & TPÇS & SÇ & YA & SA & KA & YOV & KOV \\
\hline Çeşitler & $1.14^{\text {od }}$ & $4.37^{*}$ & $3.66^{*}$ & $3.70^{*}$ & $8.18^{* *}$ & $23.45^{\text {od }}$ & $2.49^{\text {od }}$ & $13.23^{* *}$ & $46.57^{* *}$ \\
Ekim Zamanları & $1.14^{\text {od }}$ & $0.14^{\text {öd }}$ & $34.07^{* *}$ & $39.62^{* *}$ & $41.54^{* *}$ & $55.18^{* *}$ & $7.26^{*}$ & $14.47^{*}$ & $38.75^{* *}$ \\
İnteraksiyon & $0.59^{\text {öd }}$ & $0.41^{\text {od }}$ & $0.63^{\text {̈d }}$ & $0.58^{\text {öd }}$ & $10.88^{* *}$ & $6.02^{* *}$ & $0.86^{\text {od }}$ & $9.51^{* *}$ & $15.58^{* *}$ \\
DK (\%) & 6.01 & 4.83 & 2.05 & 10.70 & 6.68 & 11.87 & 17.19 & 8.69 & 4.96 \\
\hline
\end{tabular}

BB; bitki boyu, YS; yaprak sayısı, TPÇS; tepe püskülü çıkarma süresi, SÇ; sap çapı, YA; yaprak ağıIlığı, SA; sap ağırlığı, KA; koçan ağırlığı, YOV; yaş ot verimi, KOV; kuru ot verimi, DK; düzeltme katsayısı, öd; önemli değil, ${ }^{*} ; \mathrm{P}<0.05,{ }^{* *} ; \mathrm{P}<0.01$

Çizelge 3'de izlendiği üzere ekim zamanı geciktikçe BB'de bir azalma eğilimi görülmüştür fakat bu azalma istatistiki açıdan önemli değildir. Farklı ekim zamanlarındaki BB 248.0-260.8 cm arasında değişmiş olup, en uzun BB 25 Şubat ekimlerinde, en kısa bitki boyu 30 Mart ekimlerinde belirlenmiştir. 25 Şubat tarihinde BB'nin 30 Mart tarihine göre daha uzun olmasının sebebinin Hatay koşullarında sıcaklığın hızlı yükselmesi ve bu sıcaklık artışına bağlı olarak bitkilerin çabuk olgunlaşarak boy artışlarını sonlandırması ve gücünü koçan gelişimine harcamasında etkili olduğu düşünülebilir. Farklı mısır çeşitlerinde ise en yüksek BB'nin $258.4 \mathrm{~cm}$ ile 70 MAY 82 çeşidinden en düşük $B B$ ise $245.5 \mathrm{~cm}$ ile P31P41 çeşidinden elde edilmiştir. Mısırda BB çevre ve yetiştirme şartlarından etkilenen kalıtsal bir özelliktir. Ot amacıyla yetiştirilen mısırda temel amaç birim alandan daha fazla yeşil aksam elde etmektir. Bu nedenle diğer özelliklerle birlikte yüksek BB'de önem arz etmektedir. Yaptığımız bu çalışmada kullanılan mısır çeşitlerinde bitki boylarının birbirine yakın olması ve istatistiki bir farkın bulunmaması 4 çeşit mısır özelliğinin FAO 700 olum grubunda olmasından kaynaklandığı düşünülebilir.

Çizelge 3. Farklı ekim zamanlarının bazı mısır çeşitlerinde bitki boyu $(\mathrm{cm})$ üzerine etkileri

Table 3. Effects of different sowing times on plant height $(\mathrm{cm})$ of some maize cultivars

\begin{tabular}{lcccc}
\hline Çeşitler & 25 Şubat & $\begin{array}{c}\text { Ekim Zamanları } \\
\text { 14 Mart }\end{array}$ & 30 Mart & Ortalama \\
\hline CARELLA F1 & 258.2 & 254.1 & 250.1 & 254.1 \\
DKC 6590 & 259.3 & 241.2 & 256.1 & 252.2 \\
70 MAY 82 & 269.4 & 253.0 & 252.9 & 258.4 \\
P31P41 & 256.4 & 247.3 & 232.8 & 245.5 \\
Ortalama & 260.8 & 248.9 & 248.0 & \\
\hline
\end{tabular}


Farklı mısır çeşitlerinde BB bakımından önemli bir fark olmadığını söyleyen Sencar ve ark. (1993)'ın bulgularıyla bizim bulgularımız paralellik göstermektedir. Bitki boyunun en az değişkenlik gösteren bir özellik olduğu Deng ve ark. (2009) tarafından da bildirilmektedir. Nitekim bu çalışmadan elde edilen BB değerleri Yılmaz ve Sağlamtimur (1996)'un değerleri ile benzerlik gösterirken, Vartanlı ve Emeklier (2007) ve Özmen (2008)'nin değerlerinden daha düşük olduğu görülmektedir.

Yapılan bu çalışmada ekim zamanı istatistiksel olarak önemsiz bulunmuş olsa da yaprak sayısının (YS) 12.6712.83 adet bitki $^{-1}$ arasında değiştiği saptanmıştır. Çalışmamızda aldığımız sonuçlara göre YS mısır bitkisinde genetik özellikler ile bağlantılı olduğu düşünülmektedir. Çizelge 4 'de görüldüğü gibi en fazla YS 25 Şubat tarihli ekimde 70 MAY 82 çeşidinden elde edilirken, en düşük ise 30 Mart tarihli ekimde CARELLA F1 çeşidinde bulunmuştur. YS'nin silaj kalitesini etkileyen önemli bir özellik olması ve bu durumun oluşmasında çeşitlerin genetik yapılarının büyük bir etken olması Güneş (2004) tarafından da bildirilmektedir. Farklı ekim zamanlarının kullanılan mısır çeşitlerinde büyüme ve gelişme faktörlerini önemli ölçüde etkilediğini ve YS'nin en az değişkenlik gösteren bir özellik olduğu Deng ve ark. (2009) tarafından da bildirilmektedir.

Çizelge 4. Farklı ekim zamanlarının bazı mısır çeşitlerinde yaprak sayısı (adet bitki ${ }^{-1}$ ) üzerine etkileri Table 4. Effects of different sowing times on leaf number (number plant ${ }^{-1}$ ) of some maize cultivars

\begin{tabular}{lcccc}
\hline Çeşitler & 25 Şubat & $\begin{array}{c}\text { Ekim Zamanları } \\
14 \text { Mart }\end{array}$ & 30 Mart & Ortalama \\
\hline CARELLA F1 & 12.33 & 12.33 & 12.67 & $12.44 \mathrm{BC}^{+}$ \\
DKC 6590 & 13.33 & 13.33 & 13.00 & $13.22 \mathrm{~A}$ \\
70 MAY 82 & 12.67 & 13.33 & 13.00 & $13.00 \mathrm{AB}$ \\
P31P41 & 12.33 & 12.33 & 12.33 & $12.33 \mathrm{C}$ \\
Ortalama & 12.67 & 12.83 & 12.75 & \\
\hline
\end{tabular}

${ }^{+}$Aynı sütun içerisinde benzer harfle gösterilen sayılar \%5 hata sınırları içerisinde birbirinden farksızdır.

Çizelge 5. Farklı ekim zamanlarının bazı mısır çeşitlerinde tepe püskülü çıkarma süresi (gün) üzerine etkileri Table 5. Effects of different sowing times on days to tasseling floret (day) of some maize cultivars

\begin{tabular}{lcccc}
\hline Çeşitler & 25 Şubat & $\begin{array}{c}\text { Ekim Zamanları } \\
14 \text { Mart }\end{array}$ & 30 Mart & Ortalama \\
\hline CARELLA F1 & 97.00 & 85.00 & 76.00 & $86.00 \mathrm{~B}^{+}$ \\
DKC 6590 & 96.00 & 86.00 & 75.00 & $85.67 \mathrm{~B}^{-00}$ \\
70 MAY 82 & 100.00 & 87.00 & 77.67 & $88.22 \mathrm{~A}$ \\
P31P41 & 98.00 & 85.00 & 77.00 & $86.67 \mathrm{AB}$ \\
Ortalama & $97.75 \mathrm{~A}^{++}$ & $85.75 \mathrm{~B}$ & $76.42 \mathrm{C}$ & \\
\hline
\end{tabular}

${ }^{+}$Aynı sütun içerisinde benzer harfle gösterilen sayılar \%5 hata sınırları içerisinde birbirinden farksızdır.

${ }^{++}$Aynı satır içerisinde benzer harfle gösterilen sayılar \%5 hata sınırları içerisinde birbirinden farksızdır.

Farklı mısır çeşitlerinde ve ekim zamanlarında belirlenen tepe püskülü çıkarma süresi (TPÇS)'ne ilişkin ortalama değerler ve oluşan gruplar Çizelge $5^{\prime}$ de verilmiştir. Farklı ekim zamanlarında TPÇS 76.42-97.75 gün arasında değişmiş olup en uzun TPÇS 25 Şubat ekiminde, en kısa TPÇS 30 Mart ekiminde belirlenmiştir. TPÇS, 30 Mart ekiminde 25 Şubat ve 14 Mart da yapılan ekimlerden önemli derecede erken gerçekleşmiştir. Bölgemizde kış mevsiminden bahara geçildiğinde hızlı sıcaklık artışları gerçekleşmekte bu sıcaklık farklılıkları bitkiyi strese sokarak hızlı tohum bağlamaya yöneltmektedir. Bu nedenle TPÇS'de dramatik bir azalma görülmektedir. Nemli ve serin havalarda çiçeklenme süresinin uzadığı, sıcak havalarda ise kısaldığı başka araştırıcılar tarafından da tespit edilmiştir (Kırtok 1998). Araştırmada kullandığımız çeşitler tepe püskülü çıkış süresi bakımından istatistiksel olarak önemli bulunmuşolup, en uzun TPÇS'nin 70 MAY 82 çeşidinde, en kısa TPÇS'nin ise DKC 6590 çeşidinde olduğu görülmektedir. Bulgularımız; Özata ve Kapar (2014)'ın değerlerinden daha yüksek çıkmıştır. Ülkemizde yetiştirilen birinci ve ikinci ürün silajık mısırla ilgili yapılan çalışmalarda da, TPÇS bakımından çeşitler arasında önemli farklar olduğu saptanmıştır (Sencar ve ark. 1993; Gözübenli ve ark. 1997; Öktem ve ark. 1999; Aktürk 2005). TPÇS'nin farklı oluşu çeşitlerin genetik yapısının farklı olması durumundan kaynaklanmaktadır (Çölkesen ve ark. 1997). 
Çizelge 6. Farklı ekim zamanlarının bazı mısır çeşitlerinde yaprak ağılığı (g bitki $\left.{ }^{-1}\right)$ üzerine etkileri Table 6. . Effects of different sowing times on leaf weight ( $\left.\mathrm{g} \mathrm{plant}^{-1}\right)$ of some maize cultivars

\begin{tabular}{lcccc}
\hline Çeşitler & & & Ekim Zamanları & Ortalama \\
\hline CARELLA F1 & 25 Şubat & 14 Mart & 30 Mart & $178.30 \mathrm{~B}^{+}$ \\
DKC 6590 & $175.00 \mathrm{de}^{+}$ & $185.30 \mathrm{~cd}$ & $174.70 \mathrm{de}$ & $165.40 \mathrm{C}$ \\
70 MAY 82 & $165.00 \mathrm{de}$ & $160.00 \mathrm{e}$ & $171.30 \mathrm{de}$ & $193.10 \mathrm{~A}$ \\
P31P41 & $216.70 \mathrm{ab}$ & $200.00 \mathrm{bc}$ & $162.70 \mathrm{de}$ & $182.80 \mathrm{AB}$ \\
Ortalama & $168.30 \mathrm{de}$ & $226.70 \mathrm{a}$ & $153.30 \mathrm{e}$ & \\
\hline
\end{tabular}

${ }^{+}$Aynı sütun ve satır içerisinde benzer harfle gösterilen sayılar \%5 hata sınırları içerisinde birbirinden farksızdır.

${ }^{++}$Aynı sütun içerisinde benzer harfle gösterilen sayılar \%5 hata sınırları içerisinde birbirinden farksızdır.

${ }^{+++}$Aynı satır içerisinde benzer harfle gösterilen sayılar \%5 hata sınırları içerisinde birbirinden farksızdır.

Çizelge 6 'da görüldüğü gibi farklı ekim zamanlarında YA 165.50-193.00 $\mathrm{g} \mathrm{bitki}^{-1}$ arasında değişmiş olup en fazla YA (193.00 $\left.\mathrm{g} \mathrm{bitki}^{-1}\right) 14$ Mart, en düşük YA (165.50 $\mathrm{g} \mathrm{bitki}^{-1}$ ) 30 Mart ekiminde belirlenmiştir. Farklı mısır çeşitlerinde YA 165.40-193.10 $\mathrm{g} \mathrm{bitki}^{-1}$ arasında değişmiş olup en fazla YA (193.10 $\left.\mathrm{g} \mathrm{bitki}^{-1}\right) 70$ MAY 82, en düşük YA ise (165.40 g bitki $\left.{ }^{-1}\right)$ DKC $6590^{\prime}$ da olduğu belirlenmiştir. Ancak en yüksek YA değerlerine baktığımız zaman, 70 MAY 82 çeşidinin değeri ile P31P41 çeşidinin değeri arasında istatistiki bir fark bulunmamaktadır.

Ekim zamanı $x$ çeşit interaksiyonu bakımından en fazla YA 14 Mart tarihli ekimde $226.70 \mathrm{~g} \mathrm{bitki}^{-1}$ ile P31P41, en az yaprak ağırlığı 30 Mart tarihli ekimde $153.30 \mathrm{~g} \mathrm{bitki}^{-1}$ olarak P31P41 çeşidinde belirlenmiştir. Mısır çeşitlerinin ekim zamanına farklı tepki göstermesi çeşitxekim zamanı interaksiyonunun önemli çıkmasına neden olmuştur. Fakat en düşük YA interaksiyon değerlerine baktığımız zaman; 30 MartxCARELLA F1, 14 Mart×DKC 6590, 30 Mart $\times 70$ MAY 82, 25 Şubat $\times D K C$ 6590, 25 Şubat×P31P41, 30 Mart×DKC 6590, ve 25 Şubat×CARELLA F1 interaksiyonları istatistiki açıdan aynı grupta yer almıştır. İnteraksiyonlar arasında en yüksek YA değerlerini değerlendirdiğimizde, 14 Mart×P31P41 ve 25 Şubat $\times 70$ MAY 82 istatistiki açıdan aynı grupta yer almıştır. Bu sonuçları bütünüyle değerlendirdiğimiz zaman, YA açısından 70 MAY 82 ve P31P41 çeşidi en yüksek ve DKC 6590 çeşidi en düşük değeri vermiştir. Ekim zamanlarında ise 14 Mart ekimi en yüksek YA 30 Mart ekimi en düşük YA sonucunu vermiştir. En yüksek YA interaksiyon değerlerinde 25 Şubat'ta 70 MAY 82 çeşidinin ekilmiş olmasıyla 14 Mart'ta P31P41 çeşidinin ekilmiş olması arasında bir fark yoktur. Erken ekimin önemli olduğu göz önünde bulundurulursa, en yüksek YA elde edilmesi için 70 MAY 82 çeşidi ile 25 Şubat tarihinde ekimin yapılması gerektiği sonucu çıkarılabilir. Silajık mısırlarda YS önemli bir etkendir. Çünkü YS'nin artışı silaj kalitesini doğru orantılı olarak artırmaktadır. Fakat YS yanında, YA'da büyük önem taşımaktadır (Güneş 2004). Yaptığımız çalışmadan elde edilen bu sonuçlar; Güneş
(2004) ve Han (2016)'ın YA değerlerinden daha düşük, Moralar (2011)'ın değerlerinden ise daha yüksek bulunmuştur. Araştırma sonuçlarının farklı çıkması; mısır bitkisinin ana ürün ve ikinci ürün olarak yetiştirilmesi ve ele alınan çeşitlerin genetik yapısı ile ekolojik faktörlerin etkisi altında meydana gelen morfolojik bir farklılık olduğunu göstermektedir. Bu sebeple çalışmanın yapıldığı çevre koşulları da düşünüldüğünde yapılan çalışmalar arasında YA açısından tam bir bağlantı kurulamaması doğal bir sonuçtur.

Farklı mısır çeşitlerinde ve ekim zamanlarında belirlenen sap ağırlığı (SA) değerlerine ait ortalama değerler ve oluşan gruplar Çizelge 7'de verilmiştir.

Çizelge 7'de görüldüğü gibi farklı ekim zamanlarında SA 295.2-410.9 $\mathrm{g} \mathrm{bitki}^{-1}$ arasında değişmiş olup en fazla sap ağırlığı (410.9 g bitki $\left.{ }^{-1}\right) 25$ Şubat, en düşük sap ağırlığı (295.2 $\mathrm{g} \mathrm{bitki}^{-1}$ ) 30 Mart ekiminde belirlenmiş̧ir. Yapılan çalışmada ekim zamanı geciktikçe $S A^{\prime}$ da bir düşüş olduğu gözlemlenmektedir. Farklı mısır çeşitlerinde SA 296.1$455.6 \mathrm{~g} \mathrm{bitki}^{-1}$ arasında değişmiş olup en fazla sap ağırlığı (455.6 $\mathrm{g} \mathrm{bitki}^{-1}$ ) 70 MAY 82, en düşük sap ağırlığı ise (296.1 g bitki ${ }^{-1}$ ) P31P41 olduğu belirlenmiştir. íkili interaksiyon bakımından en fazla SA $580.0 \mathrm{~g}$ bitki $^{-1}$ ile 25 Şubat tarihli ekimde 70 MAY 82 çeşidinde, en az SA 208.7 g bitki ${ }^{-1}$ ile 30 Mart tarihli ekimde P31P41 çeşidinde belirlenmiştir. Mısır çeşitlerinin ekim zamanına farklı tepki göstermesi çeşitxekim zamanı interaksiyonunun önemli çıkmasına neden olmuştur. En düşük SA interaksiyon değerlerine baktığımız zaman; 30 Mart×DKC 6590, 25 Şubat×P31P41 interaksiyonları kendi aralarında istatistiki açıdan aynı grupta yer alırken, 30 Mart×P31P41 interaksiyonu en düşük değeri vermiştir. İnteraksiyonlar arasında en yüksek SA değerlerini değerlendirdiğimizde, 25 Şubat×70 MAY 82 olduğu görülmektedir. Bu nedenle en yüksek SA elde edilebilmesi için erken ekimin önemli olduğu ve 70 MAY 82 çeşidi ile 25 Şubat tarihinde ekimin yapılması gerektiği sonucu çıkarılabilir. SA ile ilgili olarak araştırmadan elde ettiğimiz sonuçlar, Moralar (2011)'ın araştırma sonuçlarından yüksek, Han (2016)'ın araştırma 
sonuçlarının ise düşük bulunmuştur. Bu farklılığın ortaya çıkmasının nedeni olarak, önceki çalışmalarda kullanılan çeşitlere göre bu çalışmada kullanılan çeşitlerin genetik özelliği ve çevresel şartlarının farklılığından kaynaklandığı düşünülmektedir.

Çizelge 7. Farklı ekim zamanlarının bazı mısır çeşitlerinde sap ağırlığı (g bitki $\left.{ }^{-1}\right)$ üzerine etkileri Table 7. Table 10. Effects of different sowing times on stem weight $\left(\mathrm{g} \mathrm{plant}^{-1}\right)$ of some maize cultivars

\begin{tabular}{lcccc}
\hline Çeşitler & 25 Şubat & $\begin{array}{c}\text { Ekim Zamanları } \\
14 \text { Mart }\end{array}$ & $30 \mathrm{Mart}$ & Ortalama \\
\hline CARELLA F1 & $370.00 \mathrm{bcde}^{+}$ & $378.70 \mathrm{bcd}$ & $328.00 \mathrm{cde}$ & $358.90 \mathrm{~B}^{++}$ \\
DKC 6590 & $390.00 \mathrm{bc}$ & $292.00 \mathrm{e}$ & $301.30 \mathrm{de}$ & $327.80 \mathrm{BC}$ \\
70 MAY 82 & $580.00 \mathrm{a}$ & $444.00 \mathrm{~b}$ & $342.70 \mathrm{cde}$ & $455.60 \mathrm{~A}$ \\
P31P41 & $303.70 \mathrm{de}$ & $376.00 \mathrm{bcd}$ & $208.70 \mathrm{f}$ & $296.10 \mathrm{C}$ \\
Ortalama & $410.90 \mathrm{~A}^{+++}$ & $372.70 \mathrm{~B}$ & $295.20 \mathrm{C}$ & \\
\hline
\end{tabular}

${ }^{+}$Aynı sütun ve satır içerisinde benzer harfle gösterilen sayılar $\% 5$ hata sınırları içerisinde birbirinden farksızdır.

${ }^{++}$Aynı sütun içerisinde benzer harfle gösterilen sayılar $\% 5$ hata sınırları içerisinde birbirinden farksızdır.

${ }^{+++}$Aynı satır içerisinde benzer harfle gösterilen sayılar $\% 5$ hata sınırları içerisinde birbirinden farksızdır.

Koçan ağırlığı (KA) değerlerine ait sonuçlar Çizelge 8'de verilmiştir. Çizelge 8 incelendiği zaman, farklı ekim zamanlarında KA 346.8-410.0 $\mathrm{g} \mathrm{bitki}^{-1}$ arasında değişmiş olup en fazla KA (410.0 g bitki $\left.{ }^{-1}\right) 25$ Şubat, en düşük KA (346.8 $\mathrm{g} \mathrm{bitki}^{-1}$ ) 30 Mart ekiminde belirlenmiştir. Ekim zamanı geciktikçe $\mathrm{KA} \mathrm{A}^{\prime} \mathrm{da}$ bir düşüş olduğu gözlemlenmektedir Aktürk (2005) ekim zamanı geciktikçe $K \mathrm{~A}^{\prime}$ da bir artış olduğunu ifade ederek çalışmamıza ters düşmektedir. Jordanov (2008), KA'nın genotiplere ve ekim zamanlarına göre değişiklik gösterdiğini bildirmiştir.

Çizelge 8. Farklı ekim zamanlarının bazı mısır çeşitlerinde koçan ağılığı (g bitki $\left.{ }^{-1}\right)$ üzerine etkileri Table 8. Effects of different sowing times on corncob weight $\left(g\right.$ plant $^{-1}$ ) of some maize cultivars

\begin{tabular}{lcccc}
\hline Çeşitler & 25 Şubat & $\begin{array}{c}\text { Ekim Zamanları } \\
14 \text { Mart }\end{array}$ & 30 Mart & Ortalama \\
\hline CARELLA F1 & 415.00 & 425.30 & 357.30 & 399.20 \\
DKC 6590 & 380.00 & 332.00 & 341.30 & 351.10 \\
70 MAY 82 & 498.30 & 401.30 & 358.70 & 419.40 \\
P31P41 & 346.70 & 378.70 & 330.00 & 351.80 \\
Ortalama & $410.00 \mathrm{~A}^{+}$ & $384.30 \mathrm{AB}$ & $346.80 \mathrm{~B}$ & \\
\hline
\end{tabular}

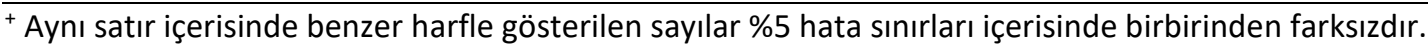

Çizelge 8'de görüldüğü gibi uygulamaların çeşitler yönünden istatistiksel olarak önemsiz olduğu bulunmuş, en fazla KA'nın 70 MAY 82 çeşidinde olduğu görülmüştür. Ekim zamanıxçeşitler interaksiyonu da istatistiksel olarak önemsiz bulunmuş olup, en fazla KA'nın 25 Şubat tarihli ekimde 70 MAY 82 çeşidinde olduğu görülmektedir. Elde edilen bu sonuçlar Sağlamtimur ve Okant (1987)'ın bulgularından daha yüksek bulunmuştur. Araştırma sonuçlarının farklı çıkması ele alınan çeşitlerin genetik yapısının farklı olabileceği intimali ile açıklanabilir. Ek olarak bitkinin yetiştirildiği yılın iklim koşulları ve bölgenin ekolojik yapısı bu farklılığın ortaya çıkmasında etkili olmuş olabilir.

Farklı mısır çeşitleri ve ekim zamanlarında belirlenmiş olan yeşil ot verimi (YOV) sonuçlarına ait ortalamalar Çizelge 9'da sunulmuştur. Çizelge 9 incelendiğinde, ele alınan mısır çeşitlerinin farklı ekim zamanlarında ki YOV değerleri 7293-8510 $\mathrm{kg} \mathrm{da}^{-1}$ arasında değişmiştir ve en yüksek YOV 25 Şubat en düşük YOV ise 30 Mart tarihli ekimlerden elde edilmiştir. Mısır çeşitlerin YOV değerleri $7093-8745 \mathrm{~kg} \mathrm{da}^{-1}$ arasında bulunmuş olup en yüksek YOV değerine 70 MAY 82 çeşidi sahip olurken en düşük YOV ise P31P41 çeşidinde bulunmuştur. İkili interaksiyon bakımından en yüksek YOV $10600 \mathrm{~kg} \mathrm{da}^{-1}$ ile 25 Şubat tarihli ekimle 70 MAY 82 çeşidinden, en düşük ise 5861 $\mathrm{kg} \mathrm{da}^{-1}$ ile 14 Mart tarihli ekimle P31P41 çeşidinden elde edilmiştir. Yapılanan çalışmanın YOV sonuçlarına göre mısır çeşitlerinin ekim zamanlarına farklı tepki göstermesi çeşitxekim zamanı interaksiyonun önemli çıkmasına sebep olmuştur. Çizelge 12 'de sunulmuş olan interaksiyon değerlerini incelediğimizde, 14 Mart×CARELLA F1, 30 Mart×70 MAY 82 ve 25 Şubat×P31P41 değerlerinin istatistiki açıdan aynı grupta yer aldığı görülmektedir. Fakat bu sonuçlara göre ele 
alınan çeşitler arasında en yüksek YOV'nin elde edilebilmesi için erken ekimin önemli olduğu ve $70 \mathrm{MAY}$ 82 çeşidi ile 25 Şubat tarihinde ekim yapılmasının yaralı olacağı çıkarılabilir. Budak ve ark. (2005) YOV açısından çeşitler arasında önemli farklılıkların olduğunu bildirmiştir. Ayrıca bu çalışmadan elde edilen YOV değerlerine ilişkin sonuçlar Yılmaz ve ark. (1999), Keskin (2001), Kılıç ve Gül (2007) ve Küçük (2011)'ün değerlerinden yüksek bulunmuş, Sencar ve ark. (1993)'nın değerlerinden ise düşük bulunmuştur. Bunun sebebi olarak hem kullanılan çeşitlerin verim potansiyellerinin farklı ve hem de bölgelerin ekolojik şartlarının birbirinden farklı olabileceği gösterilebilir. Demiray (2013), silajlık mısır tarımında yüksek verim almanın en önemli yollarından birinin bol yeşil aksam elde edebilmek için doğru çeşit seçiminin olduğunu bildirmiştir.

Çizelge 9. Farklı ekim zamanlarının bazı mısır çeşitlerinde yeşil ot verimi $\left(\mathrm{kg} \mathrm{da}^{-1}\right)$ üzerine etkileri

Table 9. Effects of different sowing times on fresh forage yield $\left(\mathrm{kg} \mathrm{da}^{-1}\right)$ of some maize cultivars

\begin{tabular}{lcccc}
\hline Çeşitler & 25 Şubat & $\begin{array}{c}\text { Ekim Zamanları } \\
14 \text { Mart }\end{array}$ & 30 Mart & Ortalama \\
\hline CARELLA F1 & $7893 \mathrm{bcd}^{+}$ & $6835 \mathrm{def}$ & $6564 \mathrm{ef}$ & $7097 \mathrm{~B}^{++}$ \\
DKC 6590 & $8520 \mathrm{~b}$ & $8743 \mathrm{~b}$ & $7214 \mathrm{cde}$ & $8159 \mathrm{~A}$ \\
70 MAY 82 & $10600 \mathrm{a}$ & $8634 \mathrm{~b}$ & $7003 \mathrm{def}$ & $8745 \mathrm{~A}$ \\
P31P41 & $7027 \mathrm{def}$ & $5861 \mathrm{f}$ & $8390 \mathrm{bc}$ & $7093 \mathrm{~B}$ \\
Ortalama & $8510 \mathrm{~A}^{+++}$ & $7518 \mathrm{~B}$ & $7293 \mathrm{~B}$ &
\end{tabular}

${ }^{+}$Aynı sütun ve satır içerisinde benzer harfle gösterilen sayılar \%5 hata sınırları içerisinde birbirinden farksızdır.

${ }^{++}$Aynı sütun içerisinde benzer harfle gösterilen sayılar \%5 hata sınırları içerisinde birbirinden farksızdır.

${ }^{+++}$Aynı satır içerisinde benzer harfle gösterilen sayılar \%5 hata sınırları içerisinde birbirinden farksızdır.

$\mathrm{Bu}$ çalışmada değerlendirilmiş olan mısır çeşitleri üzerinde farklı ekim zamanlarının kuru ot verimi üzerine etkilerini gösteren ortalama karşılaştırma testi sonuçları Çizelge $10^{\prime}$ da verilmiştir.

Çizelge 10. Farklı ekim zamanlarının bazı mısır çeşitlerinde kuru ot verimi $\left(\mathrm{kg} \mathrm{da}^{-1}\right)$ üzerine etkileri Table 10. Effects of different sowing times on dry forage yield $\left(\mathrm{kg} \mathrm{da}^{-1}\right)$ of some maize cultivars

\begin{tabular}{lcccc}
\hline Çeşitler & 25 Şubat & $\begin{array}{c}\text { Ekim Zamanları } \\
14 \text { Mart }\end{array}$ & 30 Mart & Ortalama \\
\hline CARELLA F1 & $2239 \mathrm{de}^{+}$ & $2237 \mathrm{de}$ & $1989 \mathrm{f}$ & $2155 \mathrm{D}^{++}$ \\
DKC 6590 & $3191 \mathrm{a}$ & $2745 \mathrm{~b}$ & $2453 \mathrm{~cd}$ & $2796 \mathrm{~A}$ \\
70 MAY 82 & $2743 \mathrm{~b}$ & $3051 \mathrm{a}$ & $2152 \mathrm{ef}$ & $2648 \mathrm{~B}$ \\
P31P41 & $2333 \mathrm{cde}$ & $2332 \mathrm{cde}$ & $2540 \mathrm{bc}$ & $2402 \mathrm{C}$ \\
Ortalama & $2627 \mathrm{~A}^{+++}$ & $2591 \mathrm{~A}$ & $2283 \mathrm{~B}$ & \\
\hline
\end{tabular}

${ }^{+}$Aynı sütun ve satır içerisinde benzer harfle gösterilen sayılar \%5 hata sınırları içerisinde birbirinden farksızdır.

${ }^{++}$Aynı sütun içerisinde benzer harfle gösterilen sayılar \%5 hata sınırları içerisinde birbirinden farksızdır.

${ }^{++}$Aynı satır içerisinde benzer harfle gösterilen sayılar \%5 hata sınırları içerisinde birbirinden farksızdır.

Çizelge 10'da görüldüğü üzere farklı ekim zamanlarında kuru ot verimi (KOV) $2283-2627 \mathrm{~kg} \mathrm{da}^{-1}$ arasında değişmiş olup, en yüksek KOV 25 Şubat tarihli ekimde en düşük KOV 30 Mart tarihli ekimde elde edilmiştir. Yapılan bu çalışmanın sonuçlarına göre ekim zamanı geciktikçe KOV'de düşüş göstermiştir. Ele alınan mısır çeşitlerinin ise KOV değerleri $2155-2796 \mathrm{~kg} \mathrm{da}^{-1}$ arasında değişiklik göstermiştir. En yüksek KOV DKC 6590, en düşük KOV ise CARELLA F1 çeşitlerinden elde edilmiştir. Geçmişte yürütülmüş bazı çalışmaları incelediğimiz zaman, bu çalışmadan elde edilen KOV değerlerine ait sonuçlar Sencar ve ark. (1993), Yılmaz ve ark. (1999), Keskin (2001), Budak ve Soya (2003) ve Küçük (2011)'ün değerlerinden daha yüksek Güneş (2004)'in değerleri ile benzerlik göstermektedir. Çizelge 10'dan de izlendiği üzere interaksiyonlar arasında en yüksek KOV 25 Şubat tarihli ekimde $3051 \mathrm{~kg} \mathrm{da}^{-1}$ ile 70 MAY 82 çeşidinden elde edilirken, en düşük KOV ise 30 Mart tarihli ekimde 1989 $\mathrm{kg} \mathrm{da}^{-1}$ ile CARELLA F1' de bulunmuştur. Bu çalışmada ele alınan mısır çeşitleri ekim zamanı faktörlerine farklı tepki verdiğinden dolayı ekim zamanı×çeşit interaksiyonları istatistiki açısından birbirinden farklı olduğu tespit edilmiştir. İnteraksiyonlar arsında en yüksek KOV açısından 25 Şubat×DKC 6590 ve 14 Mart×70 MAY 82 aynı grupta yer almıştır ve bu iki interaksiyon arasında istatistiki bir fark yoktur. Erken ekimin önemli olduğu ön 
planda tutulursa en yüksek KOV için bu bölgede ve/veya aynı ekolojik şartları temsil eden bölgelerde DKC 6590 çeşidi ile 25 Şubat tarihinde ekimin yapılması faydalı olacaktır. Geren ve ark. (2003)'nın KOV'inde ekim zamanı ile çeşit etkisinin önemli olduğunu vurgulamaları bu çalışmadan elde edilen sonuçları destekler niteliktedir. KOV bakımından çeşitler arasında ortaya çıkan farklılık çeşitlerin genetik yapısının dolayısıyla morfolojik, fizyolojik ve fenolojik özelliklerinin değişik olmasından kaynaklandığı düşünülmektedir.

Çizelge 11. İncelenen bazı kalite parametrelerine ilişkin $\mathrm{F}$ testi ve önemlilik seviyeleri

Table 11. F test results and significance levels of investigated some quality parameters

\begin{tabular}{lccccccc}
\hline \multirow{2}{*}{ Faktörler } & & \multicolumn{5}{c}{ F Değerleri } & \\
& HPO & NDF & ADF & KMT & NE L $^{*}$ & NYD & SKM \\
\hline Ekim Zamanları & $12.02^{*}$ & $14.77^{*}$ & $20.29^{* *}$ & $16.22^{*}$ & $19.86^{* *}$ & $12.77^{*}$ & $19.10^{* *}$ \\
Çeşitler & $11.59^{* *}$ & $1.71^{\text {od }}$ & $1.33^{\text {od }}$ & $1.32^{\text {od }}$ & $1.40^{\text {öd }}$ & $1.15^{\text {od }}$ & $1.34^{\text {od }}$ \\
Interaksiyon & $3.12^{*}$ & $4.75^{* *}$ & $0.27^{\text {öd }}$ & $4.31^{* *}$ & $0.27^{\text {öd }}$ & $3.08^{*}$ & $0.27^{\text {od }}$ \\
DK (\%) & 14.74 & 7.20 & 10.63 & 6.97 & 3.64 & 8.39 & 2.58 \\
\hline
\end{tabular}

HPO; ham protein oranı, NDF; nötr ortamda çözünmeyen lif, ADF; asitli ortamda çözünmeyen lif, KMT; kuru madde tüketimi, NE net enerji laktasyon, NYD; nispi yem değeri, SKM; sindirilebilir kuru madde, DK; düzeltme katsayısı, öd; önemli değil, ${ }^{*} ; \mathrm{P}<0.05,{ }^{* *}$; $\mathrm{P}<0.01$

Çizelge 11'de bazı kalite kriterlerine ilişkin varyans analizi sonuçları verilmiştir. HPO (ham protein oranı) açısından ekim zamanları, çeşitler ve interaksiyonlar istatistiki açıdan önemli bulunmuştur. NDF, ADF, KMT, NE $L$, NYD ve SKM özelliklerinde ekim zamanları istatistiksel olarak önemli bulunurken, çeşitler önemsiz çıkmıştır. Ayrıca yine aynı özelliklerden interaksiyonlarda NDF, KMT ve NYD istatistiki açıdan önemli bulunmuş olup, diğer özelliklerde ise istatistiki bir fark bulunmamıştır.

Çizelge 12'de HPO değerlerine ait ortalama sonuçlar verilmiştir.

Çizelge 12. Farklı ekim zamanlarının bazı mısır çeşitlerinde ham protein oranı (\%) üzerine etkileri

Table 12. Effects of different sowing times on crude protein rate (\%) of some maize cultivars

\begin{tabular}{lcccc}
\hline Çeşitler & 25 Şubat & $\begin{array}{c}\text { Ekim Zamanları } \\
14 \text { Mart }\end{array}$ & 30 Mart & Ortalama \\
\hline CARELLA F1 & $7.44 \mathrm{bcd}^{+}$ & $6.85 \mathrm{~cd}$ & $6.06 \mathrm{~d}$ & $6.78 \mathrm{BC}^{++}$ \\
DKC 6590 & $5.79 \mathrm{~d}$ & $6.46 \mathrm{~d}$ & $6.23 \mathrm{~d}$ & $6.16 \mathrm{C}$ \\
70 MAY 82 & $11.24 \mathrm{a}$ & $6.97 \mathrm{bcd}$ & $8.84 \mathrm{bc}$ & $9.02 \mathrm{~A}$ \\
P31P41 & $8.99 \mathrm{~b}$ & $7.16 \mathrm{bcd}$ & $6.75 \mathrm{~d}$ & $7.63 \mathrm{~B}$ \\
Ortalama & $8.37 \mathrm{~A}^{+++}$ & $6.86 \mathrm{~B}$ & $6.97 \mathrm{~B}$ & \\
\hline
\end{tabular}

${ }^{+}$Aynı sütun ve satır içerisinde benzer harfle gösterilen sayılar $\% 5$ hata sınırları içerisinde birbirinden farksızdır.

${ }^{++}$Aynı sütun içerisinde benzer harfle gösterilen sayılar $\% 5$ hata sınırları içerisinde birbirinden farksızdır.

${ }^{+++}$Aynı satır içerisinde benzer harfle gösterilen sayılar $\% 5$ hata sınırları içerisinde birbirinden farksızdır.

Çizelge 12.'de görüldüğü üzere, en yüksek ham protein (HP) oranı 25 Şubat tarihli ekimde 70 MAY 82 çeşidinde \%11.24 olarak tespit edilirken, en düşük HP yine 25 şubat tarihli ekimde DKC 6590 çeşidinde \%5.79 olarak bulunmuştur. Bu sonuçlara göre alınan mısır çeşitleri HP açısından ekim zamanlarına karşı farklı tepki göstermişlerdir. DKC 6590 çeşidinin ekim zamanı geciktikçe $\mathrm{HP}^{\prime} \mathrm{i}$ azalmıştır. En düşük ham protein oranı interaksiyon değerlerine baktığımız zaman; 25 Şubat×DKC 6590, 30 Mart×CARELLA F1, 14 Mart×DKC 6590, 30 Mart×DKC 6590, 30 Mart×P31P41 interaksiyonları istatistiki açıdan aynı grupta yer almıştır. Interaksiyonlar arasında en yüksek ham protein oranı değerini değerlendirdiğimizde, 25 şubat×70 MAY 82 interaksiyonunun öne çıktığı tespit edilmiştir. Ham protein oranının vejetasyon süresi uzadıkça arttığı düşünülmektedir. Geren (2000) ve Geren ve ark. (2003)'nın ham protein veriminde ekim zamanı ve çeşit etkisinin önemli olduğunu bildirmesi çalışmamızla benzerlik göstermektedir. Ülkemizin faklı bölgelerinde silajlık mısır ile ilgili yapılan araştırmalarda ham protein oranı bakımından farklı değerler elde edilmiştir. Bulgularımız; Küçük (2011), Özata ve Kapar (2014)'ın değerlerinden düşük, Güneş (2004) ve Bayram (2010)'ın HP değerlerinden ise yüksek çıkmıştır. Bu farlılıkların nedenleri; kullanılan çeşitlerin genetik özelliklerinin, ekim zamanlarının, yetiştirme tekniklerinin ve 
denemelerin yürütüldüğü çevre faktörlerinin farklı olmasından kaynaklandığı düşünülmektedir.

Farklı mısır çeşitlerinde ve ekim zamanlarında belirlenen ADF değerlerine ait ortalama değerler ve oluşan gruplar Çizelge $13^{\prime}$ de verilmiştir. Çizelge $13^{\prime}$ de görüldüğü gibi farklı ekim zamanlarında ADF \%21.35-23.24 arasında değişmiş olup en yüksek ADF oranı (\%23.24) 14 Mart, en düşük ADF oranı (\%21.35) 30 Mart tarihli ekimde belirlenmiştir. Çeşitler arasında ise en yüksek ADF oranı 70 MAY 82 çeşidinde olduğu görülmektedir.
Interaksiyonlar istatistiksel açıdan önemli bulunmamış olup, intreraksiyonlar arasında en yüksek ADF oranı 14 Mart tarihli ekimde 70 MAY 82 çeşidinde tespit edilmiştir. Bu çalışmadan elde edilen ADF sonuçları Bayram (2010)'ın sonuçlarından daha düşük bulunmuştur. Hayvanlarda sindirimin optimum seviyede olması için ADF oranının \%28-32 değerleri arasında olması gereklidir (Van Soest 1994). Ateş (2012), ADF oranının \%30 ve altında olmasının istenildiğini belirtmiştir.

Çizelge 13. Farklı ekim zamanlarının bazı mısır çeşitlerinde ADF oranı (\%) üzerine etkileri

Table 13. Effects of different sowing times on ADF rate (\%) of some maize cultivars

\begin{tabular}{lcccc}
\hline Çeşitler & 25 Şubat & $\begin{array}{c}\text { Ekim Zamanları } \\
14 \text { Mart }\end{array}$ & 30 Mart & Ortalama \\
\hline CARELLA F1 & 23.33 & 23.30 & 21.06 & 22.56 \\
DKC 6590 & 21.80 & 21.67 & 20.95 & 21.47 \\
70 MAY 82 & 22.98 & 24.67 & 22.76 & 23.47 \\
P31P41 & 21.09 & 23.34 & 20.64 & 21.69 \\
Ortalama & $22.30 \mathrm{~B}^{+}$ & $23.34 \mathrm{~A}$ & $21.35 \mathrm{C}$ & \\
\hline
\end{tabular}

${ }^{+}$Aynı satır içerisinde benzer harfle gösterilen sayılar \%5 hata sınırları içerisinde birbirinden farksızdır.

Farklı mısır çeşitlerinde ve ekim zamanlarında belirlenen NDF değerlerine ait ortalama karşılaştırma testi sonuçları Çizelge 14.'de verilmiştir. Bazı mısır çeşitlerinin farklı ekim zamanlarında NDF değerleri \%44.72-\%54.58 arasında değişmiş olup, en yüksek NDF oranı (\%54.58) 30 Mart tarihli ekimde elde edilirken, en düşük (\%44.72) ise 25 Şubat tarihli ekimde bulunmuştur. Yapılan bu çalışmaya ekim zamanı geciktikçe NDF oranı artmıştır. Interaksiyon bakımından en yüksek NDF oranı \%61.76, en düşük NDF oranı ise $\% 42.78$ olarak belirlenmiştir. Mısır çeşitlerinin ekim zamanına farklı tepki göstermesi çeşitxekim zamanı interaksiyonunun önemli çıkmasına neden olmuştur. Tüm çeşitlerde ekim zamanı geciktikçe NDF değerinde artış olduğu gözlenmiştir. Interaksiyon değerleri arasında en düşük NDF oranı 25 Şubat×P31P41'de olduğu belirlenirken, en yüksek NDF oranı ise 30 Mart $\times 70$ MAY 82 uygulamasında bulunmuştur. Fakat en 30 Mart×70 MAY 82 uygulaması ile 30 Mart×P31P41 uygulaması arasında istatistiki bir fark yoktur. Bu çalışmadan elde edilen NDF sonuçları ile ilgili bulgularımız Bayram (2010)'ın değerlerinden daha düşük bulunmuştur. Yemdeki yüksek NDF değerinin sindirimi yavaşlatması sebebi ile fiziksel olarak hayvanda tokluk hissi yaratarak hayvanın aldığı yem miktarında azalmaya neden olmakta ve hayvanın aldığı yem miktarı düşmektedir (Van Soest, 1994). Ateş (2012), NDF oranının $\% 40$ ve altında bir değer olması gerektiğini belirtmiştir.

Çizelge 14. Farklı ekim zamanlarının bazı mısır çeşitlerinde NDF oranı (\%) üzerine etkileri

Table 14. Effects of different sowing times on NDF rate (\%) of some maize cultivars

\begin{tabular}{|c|c|c|c|c|}
\hline \multirow{2}{*}{ Çeşitler } & \multicolumn{3}{|c|}{ Ekim Zamanları } & \multirow{2}{*}{ Ortalama } \\
\hline & 25 Şubat & 14 Mart & 30 Mart & \\
\hline CARELLA F1 & $45.34 \mathrm{ef}^{+}$ & 51.43 bcde & $46.91 \mathrm{cdef}$ & 47.89 \\
\hline DKC 6590 & 44.78 ef & $52.50 \mathrm{bcd}$ & 53.56 bc & 50.28 \\
\hline 70 MAY 82 & 45.95 def & 46.63 def & $61.76 \mathrm{a}$ & 51.45 \\
\hline P31P41 & $42.78 \mathrm{f}$ & 47.81 cdef & $56.10 \mathrm{ab}$ & 48.90 \\
\hline Ortalama & $44.72 \mathrm{~B}^{++}$ & $49.59 \mathrm{AB}$ & $54.58 \mathrm{~A}$ & \\
\hline
\end{tabular}

${ }^{+}$Aynı sütun ve satır içerisinde benzer harfle gösterilen sayılar hata sınırları içerisinde birbirinden farksızdır.

${ }^{++}$Aynı satır içerisinde benzer harfle gösterilen sayılar \%5 hata sınırları içerisinde birbirinden farksızdır.

Kuru madde tüketile bilirliği (KMT) toplam hücre duvarı bileşenlerini ifade eden NDF üzerinden hesaplanarak, o yemi hayvanın teorik olarak canlı ağırlı̆ı̆ın yüzdesi olarak ne kadar tüketebileceğini gösteren bir değerdir. Bu sebeple hesaplanan KMT değerleri NDF içerikleri ile oldukça paralellik göstermektedir. Farklı mısır 
çeşitlerinde ve ekim zamanlarında belirlenen KMT değerlerine ait ortalama değerler ve oluşan gruplar Çizelge $15^{\prime}$ de verilmiştir.

Çizelge $15^{\prime}$ de izlendiği üzere farklı ekim zamanlarında KMT \%2.23-2.69 arasında değişiklik göstermiştir. En yüksek KMT (\%2.69) 25 Şubat tarihli ekimden elde edilirken, en düşük (\%2.23) ise 30 Mart tarihli ekimde bulunmuştur. Ekim zamanı geciktikçe KMT oranında bir düşüş meydana gelmiştir. Interaksiyonlar bakımından en yüksek KMT 25 Şubat tarihli ekimde P31P41 çeşidinde, en düşük KMT ise 30 Mart tarihli ekimde \%1.96 ile 70 MAY 82 çeşidinde bulunmuştur. Çalışmamızda elde ettiğimiz KMT oranı değerleri Okan (2015)'ın değerlerinden yüksek çıkmıştır.

Çizelge 15. Farklı ekim zamanlarının bazı mısır çeşitlerinde KMT üzerine etkileri

Table 15. Effects of different sowing times on ADF rate (\%) of some maize cultivars

\begin{tabular}{|c|c|c|c|c|}
\hline \multirow{2}{*}{ Çeşitler } & \multicolumn{3}{|c|}{ Ekim Zamanları } & \multirow{2}{*}{ Ortalama } \\
\hline & 25 Şubat & 14 Mart & 30 Mart & \\
\hline CARELLA F1 & $2.65 \mathrm{ab}^{+}$ & 2.33 bcde & $2.59 a b c$ & 2.53 \\
\hline DKC 6590 & $2.68 \mathrm{a}$ & $2.30 \mathrm{cde}$ & 2.24 def & 2.41 \\
\hline 70 MAY 82 & $2.62 \mathrm{abc}$ & $2.58 \mathrm{abc}$ & $1.96 \mathrm{f}$ & 2.39 \\
\hline P31P41 & $2.81 \mathrm{a}$ & $2.52 \mathrm{abcd}$ & 2.14 ef & 2.49 \\
\hline Ortalama & $2.69 \mathrm{~A}^{++}$ & $2.43 \mathrm{~B}$ & $2.23 \mathrm{~B}$ & \\
\hline
\end{tabular}

${ }^{+}$Aynı sütun ve satır içerisinde benzer harfle gösterilen sayılar \%5 hata sınırları içerisinde birbirinden farksızdır.

${ }^{++}$Aynı satır içerisinde benzer harfle gösterilen sayılar \%5 hata sınırları içerisinde birbirinden farksızdır.

Farklı mısır çeşitlerinde ve ekim zamanlarında belirlenen net enerji laktasyon (NEL) değerlerine ait ortalama değerler ve oluşan gruplar Çizelge 16.'da verilmiştir. Farklı ekim zamanlarında $\mathrm{NE}_{\mathrm{L}}$ 1.69-1.74 Mcal kg-1 arasında değişmiş olup en yüksek NEL (1.74 $\mathrm{Mcal} \mathrm{kg}^{-1}$ ) 30 Mart, en düşük $\mathrm{NE}_{\mathrm{L}}$ (1.69 Mcal kg-1) 14 Mart ekiminde belirlenmiştir. $\mathrm{NE}_{\mathrm{L}}$ çeşitler yönünden istatistiksel olarak

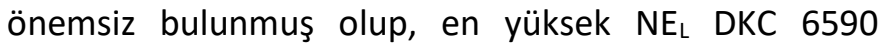

çeşidinde olduğu görülmektedir. Ekim zamanıxçeşitler interaksiyonu da istatistiksel olarak önemsiz bulunmuş olup, en yüksek $\mathrm{NE}_{\mathrm{L}} 30$ Mart tarihli ekimde P31P41 çeşidinde olduğu belirlenmiştir. Farklı ekim zamanları arasındaki $\mathrm{NE}_{\mathrm{L}}$ değerlerini karşılaştırdığımızda yüksek değere sahip olan uygun ekim zamanının hayvanın enerji ihtiyacının karşılanmasında daha etkin olduğunu söyleyebiliriz.

Çizelge 16. Farklı ekim zamanlarının bazı mısır çeşitlerinde net enerji laktasyon ( $\mathrm{NE}_{\mathrm{L}}$ ) üzerine etkileri Table 16. Effects of different sowing times on net energy lactation $\left(N E_{L}\right)$ of some maize cultivars

\begin{tabular}{lcccc}
\hline Çeşitler & 25 Şubat & $\begin{array}{c}\text { Ekim Zamanları } \\
14 \text { Mart }\end{array}$ & 30 Mart & Ortalama \\
\hline CARELLA F1 & 1.69 & 1.69 & 1.75 & 1.71 \\
DKC 6590 & 1.73 & 1.73 & 1.75 & 1.74 \\
70 MAY 82 & 1.70 & 1.65 & 1.70 & 1.68 \\
P31P41 & 1.75 & 1.69 & 1.76 & 1.73 \\
Ortalama & $1.72 \mathrm{~B}^{+}$ & $1.69 \mathrm{C}$ & $1.74 \mathrm{~A}$ & \\
\hline
\end{tabular}

${ }^{+}$Aynı satır içerisinde benzer harfle gösterilen sayılar \%5 hata sınırları içerisinde birbirinden farksızdır.

Farklı mısır çeşitlerinde ve ekim zamanlarında belirlenen NYD değerlerine ait ortalama değerler ve oluşan gruplar Çizelge 17 'de verilmiştir. Farklı ekim zamanlarında NYD değerleri 125.3-149.3 arasında değişmiş olup en yüksek NYD değeri (149.3) 25 Şubat, en düşük NYD değeri (125.3) 30 Mart ekiminde belirlenmiştir. Çizelge 17'de görüldüğü gibi NYD çeşitler yönünden önemsiz bulunmuş ancak en yüksek NYD CARELLA F1 çeşidinden elde edilmiştir. İnteraksiyonlar bakımından en yüksek NYD 157.7, en düşük ise 108.3 olarak bulunmuştur.
CARELLA F1 çeşidi NYD bakımından ekim zamanına farklı tepki göstermezken diğer çeşitlerde ekim zamanı geciktikçe nispi yem değerinde düşüş olduğu belirlenmişstir. Bu çalışmadan elde edilen NYD ile ilgili sonuçlar Okan (2015)'ın değerlerinden daha yüksek bulunmuştur. Rohweder ve ark. (1978)'nın belirttiği NYD aralığı, yaptığımız çalışmada 25 Şubat tarihli ekimde P31P41 çeşidi dışındaki tüm çeşitlerdeki değerler ile paralellik göstermektedir. 
Çizelge 17. Farklı ekim zamanlarının bazı mısır çeşitlerinde nispi yem değeri (NYD) üzerine etkileri Table 17. Effects of different sowing times on relative feed value (RFV) of some maize cultivars

\begin{tabular}{lcccc}
\hline Çeşitler & & & & Ekim Zamanları \\
& 25 Şubat & 14 Mart & 30 Mart & Ortalama \\
\hline CARELLA F1 & $145.7 \mathrm{abc}^{+}$ & $127.7 \mathrm{bcde}$ & $145.7 \mathrm{abc}$ & 139.7 \\
DKC 6590 & $149.7 \mathrm{ab}$ & $128.3 \mathrm{bcde}$ & $126.3 \mathrm{cde}$ & 134.8 \\
70 MAY 82 & $144.3 \mathrm{abc}$ & $139.7 \mathrm{abcd}$ & $108.3 \mathrm{e}$ & 130.8 \\
P31P41 & $157.7 \mathrm{a}$ & $138.0 \mathrm{abcd}$ & $120.7 \mathrm{de}$ & 138.8 \\
Ortalama & $149.3 \mathrm{~A}^{++}$ & $133.4 \mathrm{~B}$ & $125.3 \mathrm{~B}$ & \\
\hline
\end{tabular}

${ }^{+}$Aynı sütun ve satır içerisinde benzer harfle gösterilen sayılar \%5 hata sınırları içerisinde birbirinden farksızdır.

${ }^{++}$Aynı satır içerisinde benzer harfle gösterilen sayılar \%5 hata sınırları içerisinde birbirinden farksızdır.

Kuru maddenin hayvan tarafından sindirilebilme oranını ifade eden ve ADF oranının kullanılmasıyla hesaplanan sindirilebilir kuru madde (SKM) sonuçları Çizelge $18^{\prime}$ de verilmiştir. Çizelge $18^{\prime}$ de izlendiği üzere SKM değerleri ekim zamanlarında 70.79-72.28 arasında değişiklik göstermiştir ve en yüksek SKM 30 Mart tarihinde elde edilirken, en düşük ise 14 Mart tarihinde belirlenmiştir. Çeşitler ve interaksiyonlar istatistiksel olarak önemsiz bulunmuştur. Çeşitler arsında en yüksek SKM P31P41 çeşidinden elde edilirken en düşük ise 70 MAY 82 çeşidinde belirlenmiştir. Interaksiyonlar arasında ise en yüksek SKM 30 Mart tarihli ekimde P31P41 çeşidinde bulunmuştur. Bu çalışmanın sonucunda elde edilen SKM değerleri Okan (2015)'ın bulgularından daha yüksek bulunmuştur. Bunun sebebi olarak ekolojik şartlar ve çeşitlerin genetik özellikleri gösterilebilir.

Çizelge 18. Farklı ekim zamanlarının bazı mısır çeşitlerinde sindirilebilir kuru madde (SKM) üzerine etkileri Table 18. Effects of different sowing times on dry matter digestibility (DDM) of some maize cultivars

\begin{tabular}{lcccc}
\hline Çeşitler & \multicolumn{3}{c}{ Ekim Zamanları } & Ortalama \\
\hline CARELLA F1 & 25 Şubat & 14 Mart & 30 Mart & 71.33 \\
DKC 6590 & 70.73 & 70.77 & 72.50 & 72.18 \\
70 MAY 82 & 71.90 & 72.03 & 72.60 & 70.61 \\
P31P41 & 71.00 & 69.67 & 71.17 & 72.00 \\
Ortalama & 72.47 & 70.70 & 72.83 & \\
\hline
\end{tabular}

${ }^{+}$Aynı satır içerisinde benzer harfle gösterilen sayılar \%5 hata sınırları içerisinde birbirinden farksızdır.

Yapılan araştırma sonucunda Hatay Amik Ovası ekolojik koşullarında yetiştirilebilecek uygun silajlık mısırda en uygun ekim zamanı hava durumunu da göz önüne alarak Şubat ayının son haftası yada Mart ayının ilk yarısında olduğu tespit edilmiştir. Bu tarihlerde yapılacak ekim ile kış yağışlarından daha fazla faydalanılacak ve buna bağlı olarak sulama suyu ihtiyacı azalacaktır. Bu çalışmanın sonuçlarına göre silajlık mısırda en verimli ve kaliteli çeşidin DKC 6590 ile 70 MAY 82 olduğu belirlenmiştir. Silajlık mısırda genel olarak DKC 6590 ile 70 MAY 82 çeşitlerinin kuru ot verimi ve ham protein oranının yüksek olması sebebi ile en verimli çeşitler olduğu düşünülmektedir. Ancak yapılan bu çalışmadaki uygulamalarda çeşitlerin farklı ekim zamanları ve çevresel faktörlerinde etkisi göz önünde bulundurulduğunda, bu konuda kesin bir yargiya ulaşabilmek için bu tip çalışmaların birkaç yıl daha sürdürülmesine ihtiyaç olduğu düşünülmektedir.

\section{ÖZET}

Amaç: Bu çalışma Hatay ekolojik koşullarında ekim zamanının ana ürün olarak yetiştirilen mısır çeşitlerinde ot verimi ve kalitesini belirlemek için 2017 yılında Amik ovası koşullarında çiftçi tarlasında yürütülmüştür.

Yöntem ve Bulgular: Denemede kullanılan ve bölgede en çok yetiştirilen P31P41, 70 May 82, DKC 6590 ve Carella F1 mısır çeşitleri 3 farklı ekim zamanında (25 Şubat, 14 Mart, 30 Mart) ekilmiştir. Araştırma tesadüf bloklarında bölünmüş parseller deneme desenine göre üç tekrarlamalı olarak yürütülmüştür. Bu çalışmada ekim zamanının farklı çeşitlerin ot verimi ve kalitesi üzerindeki etkisini belirleyebilmek için bitki boyu (BB), yaprak sayısı (YS), tepe püskülü çıkarma süresi (TPÇS), sap çapı (SÇ), yaprak ağırlığı (YA), sap ağırlığı (SA), koçan ağırlığı (KA), yeşil ot verimi (YOV), kuru ot verimi (KOV), ham protein oranı (HPO), nötr ortamda çözünmeyen lif (NDF), asit ortamda çözünmeyen lif (ADF), kuru madde tüketimi (KMT), net enerji laktasyon ( $\left.N E_{L}\right)$, nispi yem değeri (NYD) 
ve kuru madde sindirimi (KMS) özellikleri incelenmiştir. Ekim zamanlarının ele alınan mısır çeşitlerinin BB ve YS özellikleri dışında kalan tüm incelenen özellikleri üzerine etkisi istatistiksel olarak önemli bulunmuştur.

Genel Yorum: Ekim zamanlarında genel olarak en yüksek YOV ve KOV 25 şubat ekim tarihinde bulunmasına rağmen en düşük ise 30 Mart ekim tarihinde elde edilmiştir. En yüksek HPO 25 Şubat ekim tarihinde elde edilirken en düşük HP 14 Mart tarihli ekimde bulunmuştur. En yüksek NDF ve ADF oranı sırasıyla 30 Mart ve 14 Mart tarihinde yapılan ekimlerden elde edilmesine rağmen en düşük ise 25 şubat ve 30 Mart tarihli ekimlerden elde edilmiştir. Çeşitlerin KMT ve NYD ekim tarihi geciktikçe azalmıştır. Çeşitlerin en yüksek KMS ve $N E_{L}$ değerleri 14 Mart tarihli ekimden elde edilirken en düşük değerler ise 25 Şubat tarihinde yapılan ekimlerden elde edilmiştir.

Çalışmanın Önemi ve Etkisi: Bu sonuçlara göre ele alınan mısır çeşitlerinin 14 Mart tarihli ekiminin ot verimi ve kalitesi açısından iyi sonuç vereceği çıkarılabilir. Fakat ele alınan bitkilerin HPO'nı bu tarihte yapılan ekimde düşük bulunmuştur.

Anahtar Kelimeler: Ekim zamanı, Mısır çeşitleri, Ot verimi, Ot kalitesi.

\section{TEŞEKKÜR}

Bu çalışma HMKÜ Bilimsel Araştırma Projeleri Koordinatörlüğü tarafından 16689 proje numarası ile desteklenen yüksek lisans tez çalışmasının bir kısmını içermektedir.

\section{ÇIKAR ÇATIŞMA BEYANI}

Yazar(lar) çalışma konusunda çıkar çatışmasının olmadığını beyan eder.

\section{ARAŞTIRMACILARIN KATKI ORANI BEYANI}

Yazarlar çalışmaya eşit oranda katkı sağlamış olduklarını beyan eder.

\section{KAYNAKLAR}

Aktürk H (2005) Hatay koşullarında ana ürün olarak yetiştirilen bazı mısır çeşitlerinde ekim zamanı ve bitki sıklığının verim ve verimle ilişkili özelliklere etkisi. Yüksek Lisans Tezi, Mustafa Kemal Üniversitesi, Fen Bil. Ens., Tarla Bitkileri ABD, $60 \mathrm{~s}$.

Anonim (2018) Türkiye İstatistik Kurumu. www.tuik.gov.tr

AOAC (1990) Official method of analysis. 15th ed., pp. 66-68. Association of Official Analytical Chemists, Washington, DC, USA.
Ates $\mathrm{E}$ (2012) The mineral, amino acid and fiber contents and forage yield of pea (pisum arvense I.), fiddleneck (Phacelie tanacetifolia Benth.) and their mixtures under dry land conditions in the western Turkey. Romanian Agricultural Research, 29: 237-244.

Bayram M (2010) ikinci ürün silajlık mısır tarımında farklı toprak işleme yöntemlerinin mısır çeşitlerinin verim ve kalitelerine etkileri. Yüksek Lisans Tezi, Gaziosmanpaşa Üniversitesi, Fen Bil. Ens., Tarım Makineleri ABD, $95 \mathrm{~s}$.

Budak B, Soya H (2003) İkinci ürün olarak yetiştirilen farklı mısır (Zea mays L.) çeşitlerinin hasıl verimleri üzerinde bir araştırma. Türkiye 5. Tarla Bitkileri Kongresi, 13-17 Ekim 2003, Diyarnakır, Türkiye. s 529532.

Çölkesen M, Öktem A, Akıncı C, Gül I, İri R (1997) Şanlıurfa ve Diyarbakır koşullarında bazı mısır çeşitlerinde farklı ekim zamanlarının verim ve verim kompenentleri üzerine etkisi. Türkiye II. Tarla Bitkileri Kongresi, 22-25 Eylül, Samsun, Türkiye. s 139-142.

Demiray YG (2013) Bingöl ili ekolojik şartlarına uygun tane mısır (Zea mays L.) çeşitlerinin belirlenmesi. Yüksek Lisans Tezi, Bingöl Üniversitesi, Fen Bil. Ens., Tarla Bitkileri ABD, $79 \mathrm{~s}$.

Deng R, Wang Y, Zhen C, Zhou Q (2009) Effect of different sowing date on the growth and development of super sweet corn. http:// en.cnki.com.cn/Article_en/CJFDTOTALFSDX200903003.htm

Ertekin I, Atış i, Yılmaz Ş, Can E, Kızılşimşek M (2019) Comparison of shrub leaves in terms of chemical composition and nutritive value. KSU Journal of Agriculture and Nature, 22(5): 781-786.

Ertekin I, Kızılşimşek M (2020) Effects of lactic acid bacteria inoculation in pre-harvesting period on fermentation and feed quality properties of alfalfa silage. Asian-Australasian Journal of Animal Sciences, 33(2): 245-253.

Geren H (2000) Ana ve ikinci ürün olarak yetiştirilen silajlık mısır (Zea mays L.) çeşitlerinde ekim zamanlarının hasıl verimleri ile silaja ilişkin tarımsal özelliklere etkisi üzerinde araştırmalar. Doktora Tezi, Ege Üniversitesi, Fen Bil. Ens., Tarla Bitkileri ABD, 251 s.

Geren H, Avcıoğlu R, Kır B, Demiroğlu G, Yılmaz U, Cevheri AC (2003) ikinci ürün silajlık olarak yetiştirilen bazı mısır çeşitlerinde farklı ekim zamanlarının verim ve kalite özelliklerine etkisi. Ege Üniversitesi Ziraat Fakültesi Dergisi, 40: 57-64. 
Gözübenli H, Ülger AC, Kılınç M, Sener O, Karadavut U (1997) Hatay koşullarında ikinci ürün tarımına uygun mısır çeşitlerinin belirlenmesi. Türkiye II. Tarla Bitkileri Kongresi, 22-25 Eylül 1997, Samsun, Türkiye. s. 153-157.

Güneş A (2004) Karaman ekolojik koşullarında silajlık hibrit mısır çeşitleri ve sorgum-sudan otu melezlerinin ikinci ürün olarak yetiştirme imkanlarının belirlenmesi. Yüksek Lisans Tezi, Selçuk Üniversitesi, Fen Bil. Ens., Tarla Bitkileri ABD, $115 \mathrm{~s}$.

Han E (2016) Bazı mısır çeşitlerinin dane verimleri ile silaj ve kalite özelliklerinin belirlenmesi. Yüksek Lisans Tezi, Ordu Üniversitesi, Fen Bil. Ens., Tarla Bitkileri ABD. $77 \mathrm{~s}$.

Jordanov G (2008) Influence of the sowing date over new Bulgarian corn hybrids productive potential. Plant Science, 45: 403-406.

Keskin S (2001) Silajık olarak yetiştirilen mısır çeşitlerinde bitki sıklığının verim ve bazı kompenentlere etkisi. Yüksek Lisans Tezi, Selçuk Üniversitesi Fen Bil. Ens., Tarla Bitkileri ABD, 56 s.

Kılıç H, Gül I (2007) Hasat zamanının diyarbakır şartlarında ikinci ürün olarak yetiştirilen mısır çeşitlerinde verim ve bazı tarımsal karakterler ile silaj kalitesine etkileri üzerine bir araştırma. Harran Üniversitesi Ziraat Fakültesi Dergisi, 11: 43-52.

Kırtok Y (1998) Mısır üretimi ve kullanımı. Kocaoluk Basım ve Yayınevi, ìstanbul. $445 \mathrm{~s}$.

Koca YO, Erekul O (2011) Bazı melez mısır çeşitlerinin performanslarının belirlenmesi. Adnan Menderes Üniversitesi Ziraat Fakültesi Dergisi, 8: 41-45.

Konak C, Demir i (1987) Mısır koçan kurduna karşı mukavemet çalışmaları. TÜBiTAK Türkiye Tahıl Sempozyumu, 6-9 Ekim 1987, Bursa, Türkiye. s. 455464.

Küçük B (2011) Bazı silajlık mısır çeşitlerinde morfolojik özelliklerin ve yem verimlerinin belirlenmesi. Yüksek Lisans Tezi, Ankara Üniversitesi, Fen Bil. Ens., Tarla Bitkileri ABD, $75 \mathrm{~s}$.

Laurer JG, Carter PR, Wood TM, Diezel G, Wiersma DW, Rand RE, Mlynarek MJ (1999) Corn hybrid response to planting date in the northern corn belt. Argonomy Journal, 91: 834-839.

Moralar E (2011) Tekirdağ ilinde yetiştirilen bazı silajlık mısır (Zea mays L.) çeşitlerinde gelişme sürecinin belirlenmesi ve verimliliklerinin tespiti. Yüksek Lisans Tezi, Namık Kemal Üniversitesi, Fen Bil. Ens., Tarla Bitkileri ABD, $64 \mathrm{~s}$.

Okan M (2015) Diyarbakır Bismil koşullarında bazı silajlık mısır çeşitlerinin verim ve kalite özelliklerinin belirlenmesi. Yüksek Lisans Tezi, Bingöl Üniversitesi, Fen Bil. Ens., Tarla Bitkileri ABD, $90 \mathrm{~s}$.
Öktem A, Öktem AG, Beyaz T (1999) Adıyaman ikinci ürün koşullarına uygun mısır (Zea mays L.) çeşitlerinin belirlenmesi. GAP I. Tarım Kongresi, 26-28 Mayıs 1999, Şanlıurfa, Türkiye. s. 885-892.

Özata E, Kapar H (2014) Bazı atdişi hibrit mısır (Zea mays indentata Sturt) genotiplerinin Samsun koşullarında kalite ve performanslarının belirlenmesi. Tarım Bilimleri Araştırma Dergisi, 7: 1-7.

Özmen i (2008) Bazı melez mısır çeşit ve genotiplerinin değişik ekim bölgelerindeki adaptasyon ve uyum yeteneklerinin belirlenmesi üzerine araştırmalar. Doktora Tezi, Ege Üniversitesi, Fen Bil, Ens., Tarla Bitkileri ABD, $128 \mathrm{~s}$

Rohweder DA, Barnes R, Jorgensen N (1978) Proposed hay grading standart based on laboratory analyses for evaluating quality. Journal of Animal Science, 47: 747759.

Sağlamtimur T (1989) Çukurova'da ekim zamanı ve bitki sıklığının üç mısır çeşidinde hasıl verimi ve bazı tarımsal karakterlere etkisi üzerinde araştırmalar. Çukurova Üniversitesi Ziraat Fakültesi Dergisi, 4: 119133.

Sağlamtimur T, Okant M (1987) Güneydoğu anadolu bölgesinde sulanabilir koşullarda II. ürün mısırda çeşit ve bitki sıkığının verim ve bazı tarımsal karakterlere etkisi üzerine bir araştırma. Türkiye'de Mısır Üretiminin Geliştirilmesi, Problemler ve Çözüm Yolları Sempozyumu, 23-26 Mart 1987, Ankara, Türkiye. s. 317-329.

Sencar Ö, Yıldırım A, Gökmen S (1993) Silaj amacıyla II. ürün olarak yetiştirilen bazı mısır çeşitlerinin hasıl ve kuru ot verimi üzerine ekim sıklığının etkileri. Turkish Journal of Agricultural And Forestry, 17: 763-773.

Van Dyke NJ, Anderson PM (2002) Interpreting a forage analysis. Alabama Cooperative Extension, Circular ANR-890.

Van Soest PJ (1994) Fiber and physicochemical properties of feeds in: nutritional ecology of the ruminant. Second Edition, Cornell University Press, Ithaca, pp. 140-155.

Van Soest PJ, Robertson JB, Lewis BA (1991) Methods for dietary fiber, neutral detergent fiber, and nonstarch polysaccharides in relation to animal nutrition. Journal of Dairy Science, 74: 3583-3597.

Vartanlı S, Emeklier Y (2007) Ankara koşullarında hibrid mısır çeşitlerinin verim ve kalite özelliklerinin belirlenmesi. Türkiye VII. Tarla Bitkileri Kongresi, 2527 Haziran 2007, Erzurum, Türkiye. s: 37-42.

Yılmaz S, Gozubenlı H, Konuskan O, Atıs I (2007) Genotype and plant density effects on corn (Zea mays L.) forage yield. Asian Journal of Plant Science, 6:538541. 
Yılmaz S, Sağlamtimur T (1996) Ana ürün mısırda üst gübre olarak uygulanan farklı form ve dozlarda azot gübresinin hasıl verimi ve kalitesine etkisi. Mustafa Kemal Üniversitesi Ziraat Fakültesi Dergisi, 1: 113124.
Yılmaz Ş, Gözübenli H, Can E, Atış i (1999) Hatay koşullarında ikinci ürün olarak yetiştirilebilecek silajık mısır (Zea mays L.) çeşitlerinin belirlenmesi üzerine bir araştırma. Türkiye III.Tarla Bitkileri Kongresi, Adana, Türkiye. s. 295-299. 